\title{
Sustainable Development Strategy of Pine Resin in Bone Regency, South Sulawesi, Indonesia
}

\author{
Andi Nurul Mukhlisa ${ }^{1,}$, and Andi Amytia Resty Dwiyanti ${ }^{2}$ \\ ${ }^{1}$ Department of Forestry, Faculty of Agriculture, Animal Husbandry and Forestry, Universitas \\ Muslim Maros, Indonesia \\ ${ }^{2}$ Department of Public Administration, STIA Prima Bone, Indonesia
}

\begin{abstract}
Production of pine sap international level in Indonesia every period of five years has decreased significantly, it is a reference to pine sap market attention on a smaller scope that district to village level-based potential. This study aims to formulate a marketing strategy to develop the market of pine resin in Bone regency. This study was conducted in Bone regency, South Sulawesi, Indonesia and held for 5 months. The analytical method used to formulate marketing strategy in this study was a semi structured interview, to analyze the data using analysis IE (internalexternal) matrix. The results of matrix calculations IFAS (internal factor analysis summary) obtained a total score of 2.85 and a matrix internal EFAS (External factors analysis summary) with a score of 3.2. The results after analyzed with IE matrix put pine resin market position of Bone Regency in the cell II, that grow and build. Recommendation development strategy of pine rosin market namely market penetration, market development, product development, integrase forward and integrase backward..
\end{abstract}

\section{Introduction}

Research results show that timber forest products from forest ecosystems are only $10 \%$, while most (90\%) other products are non-timber forest products (HHBK) (Regulation of the Minister of Forestry of the Republic of Indonesia Number P.21/Menhut-II / 2009). Several problems related to the utilization of NTFPs include the absence of data on the potential, distribution and utilization of NTFPs, both the known and unknown benefits [1].

One form of utilization of NTFPs that has very good potential comes from tusam, which is capable of producing sap. The sap produced by pine is gondorukem and turpentine [2]. Since 1985 until now the marketing of gondorukem has been more oriented towards meeting foreign needs, namely 60 to 86 percent. This is because the demand for gondorukem in the international market continued to increase, namely as much as $347,462,314 \mathrm{~kg}$ in 2005 . In addition, the price of gondorukem in the international market

\footnotetext{
* Corresponding author: mukhlisanurul@umma.ac.id
} 
was also higher, namely US \$ 511.2 or Rp. 5,025,096, compared to domestic ones. which is IDR 4,280,426,747 per ton [3]. Gondorukem is also one of the leading NTFPs commodities in Sulawesi [4].

The potential for pine forests in South Sulawesi is spread across several districts, including Bone Regency. This business opportunity has constraints in ensuring the availability of raw materials for the production of pine sap. In addition, downstream industrial market development is also not being developed (Regulation of the Minister of Forestry of the Republic of Indonesia Number P.19 / Menhut-II / 2009).

Based on research conducted by scholar, the development of community pine forests into gondorukem is expected to be a solution to problems that occur in the community [5]. In addition, this development will have positive implications for the development of other industrial sectors $[5,6]$. Therefore, this study aims to formulate a marketing strategy for pine resin in Bone Regency.

\section{Research Methodology}

The study was conducted for five months in Bone Regency, South Sulawesi. The data needed in this study include primary and secondary data. The method of data collection is done by using purposive sampling method. Data obtained through observation activities with direct interviews with respondents using interview guides. The questions posed are a series of open questions where only the subject matter of the question is displayed which then develops with a series of questions regarding conditions, opinions and suggestions from the respondent. Respondents selected were the Head of the Regional Technical Implementation Unit (UPTD) of the Bone Regency Forestry Service, employees of the pine sap tapping industry and pine sap tapping farmer groups scattered in several sub-districts in Bone Regency, namely Tellu Limpoe District, Bontocani District, Ponre District, and Lappariaja District. The sample of pine sap tappers was determined by purposive sampling. Respondents were selected based on company partners who received permission to collect pine sap in Bone District.

The formulation of a marketing strategy was carried out using three stages of data analysis. In more detail, the stages of data analysis are as follows [7]. The matrices used in this stage are the Internal Factor Analysis Summary (IFAS) and the External Factor Analysis Summary (EFAS). At this stage, the matrix used is the IE matrix (internalexternal). The score results from the IFAS and EFAS matrices determine the competitive position of Bone District pine resin business in the IE matrix [7].

\section{Research Result}

\subsection{Potential of Pine Sap}

The Forestry and Plantation Service of Bone Regency has issued permits for the utilization of non-timber forest products in the form of pine sap to 19 farmer groups that have partnered with 5 pine sap collecting companies in South Sulawesi.

Pine sap production in Bone Regency is still fluctuating. The pine sap production data in Bone Regency has not been maximized because several farmer groups have experienced the termination of the tapping period (PT. Rakindo Utama Makmur) and some are still pioneering reforms to carry out tapping with a limited number of tapping personnel. 


\subsection{Pine Sap Market Development Strategy}

After the input process, Figure 1 shows the development of pine sap in Bone Regency in second position. After the analysis is carried out, it can be seen the strategies that can be used in the development of pine sap in Bone Regency as shown in Table 1.

THE IFE TOTAL WEIGHTED SCORES

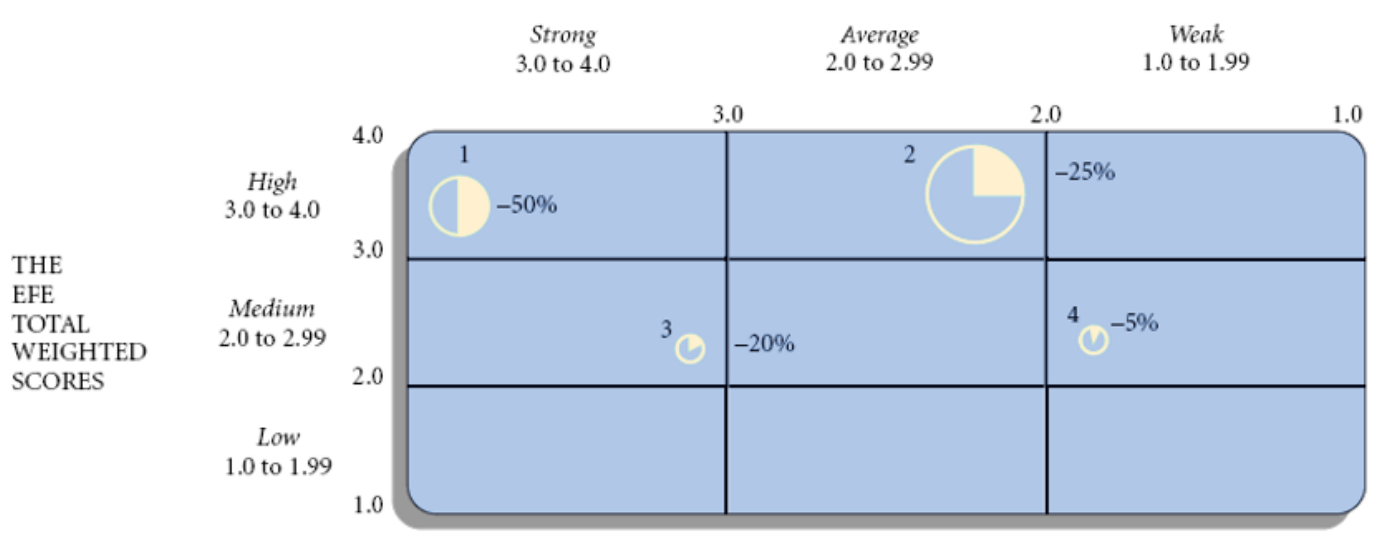

Fig. 1. IE Matrix of the increase of pine sap in the regency

Table 1. Priority strategy based on QSPM Analysis

\begin{tabular}{|c|c|c|c|c|}
\hline NO & Strategy & SWOT Analysis & $\begin{array}{l}\text { QSPM } \\
\text { Value }\end{array}$ & Priority \\
\hline 1 & Market Penetration & Increase market promotions of pine sap & 4.23 & IV \\
\hline \multirow[t]{3}{*}{2} & $\begin{array}{l}\text { Market } \\
\text { Development }\end{array}$ & $\begin{array}{l}\text { Strenghten the communications and cooperations between the } \\
\text { forestry and plantation service, pine sap companies and } \\
\text { communities around the tapping areas as the tapper }\end{array}$ & \multirow[t]{3}{*}{3.96} & \multirow[t]{3}{*}{$\mathbf{V}$} \\
\hline & & Increasing the human resources & & \\
\hline & & Maintain the stability price of pine sap & & \\
\hline \multirow[t]{4}{*}{3} & \multirow{4}{*}{$\begin{array}{l}\text { Product } \\
\text { Development }\end{array}$} & Increase the productivity of pine sap & \multirow[t]{4}{*}{4.93} & \multirow[t]{4}{*}{ II } \\
\hline & & Developing an environmentally friendly pine sap tappy technology & & \\
\hline & & Increase the quality of pine sap & & \\
\hline & & $\begin{array}{l}\text { Conduct training and socialization to increase understanding in the } \\
\text { community }\end{array}$ & & \\
\hline 4 & $\begin{array}{l}\text { Forward } \\
\text { Integration }\end{array}$ & $\begin{array}{l}\text { Build a pine resin processing plant in to gondorukem and } \\
\text { turpentine in Bone Regency }\end{array}$ & 4.5 & III \\
\hline 5 & Preview Integration & Provide opportunities for the development of agroforestry patterns & 5.39 & $\mathbf{I}$ \\
\hline
\end{tabular}




\section{Discussion}

This study provides an alternative strategy for developing pine sap which is a priority through QSPM analysis, namely market penetration, market development, product development, forward integration and backward integration. Tapping of pine sap is something new for people in Bone Regency. This makes pine sap production not optimal.

The result of the identification carried out was the establishment of cooperation from the Forestry Service, the company and the pine sap tapping farmer groups. In addition, the availability of raw materials in the form of large pine stands. Referring to scholar, the spacing of pine stands in overcoming water problems and maximizing sap production is $4 \mathrm{~m}$ $\mathrm{x} 4 \mathrm{~m}$, so that the potential for pine stands is \pm 4 million trees [8]. The resulting production is very potential, according to the company CV. Nusantara jaya, PT. Keichem Indonesia. and PT. Adimitra Pinus Utama stated that the quality and production of Bone Regency is the best after Gowa Regency. However, its production is not supported by a sufficient number of workers. If referring to other scholar, the production of Pinus merkusii is around $6.0 \mathrm{~kg} /$ tree in a year, therefore with \pm 4 million trees are able to produce pine sap $\pm 24,000$ tons / year [9]. Each company can only tolerate the presence of $2 \%$ dirt and water. Based on report, the characteristics of moisture and dirt content not exceeding $2 \%$ are classified as a quality.

The development of pine sap in Bone Regency has not experienced a smooth road, including insufficient workforce in tapping, community interest and inadequate facilities prepared. At PT. Adimitra Pinus Utama, which has a pine resin processing factory in Gowa Regency, has a minimum production standard of 3000 tons / year. Meanwhile, in Bone District, the productivity of pine sap in the year2015 was 846.51 tonnes. A pine sap processing plant can be established at least following the standards of PT. Adimitra Pinus Utama. Therefore, it is necessary to increase productivity of pine sap. The establishment of a pine sap processing factory is expected to reduce expenses in terms of transportation costs. In addition, the revenue of Bone Regency will increase with the development of a pine resin processing factory, which can ensure the sustainability of pine sap management.

In the formulation of strategies using the IE matrix, the position of the pine resin development in Bone Regency is in second position. According to scholar, the second position is in a position to grow and build [7].

\section{Conclusions and Suggestions}

The strategy that can be used to develop pine sap tapping in Bone Regency is the development of agroforestry patterns. In addition, a strategy to increase productivity and quality needs to be done to build physical facilities in the form of a pine sap processing factory. increasing productivity and quality of pine sap needs to be supported by promotional activities. Promotion through various media and increasing human resources is expected to be able to maintain price stability in order to improve the welfare of pine sap tappers. So it still needs further research on agroforestry patterns that are suitable to be juxtaposed with Pinus merkusii plants that grow in every area of Bone Regency. In addition, it is hoped that there will be research on the post-harvest process of pine sap in Bone Regency. 


\section{References}

1. J. Sihombing, Pemanfaatan Hasil Hutan Bukan Kayu (HHBK) Oleh Masyarakat Desa Sekitar Hutan Di IUPHHK-HA PT. Ratah Timber Samarinda Kalimantan Timur. Departemen Manajemen Hutan, Institut Pertanian Bogor, 2011

2. A. R. E. Surbakti, R. Batubara, and M. Muhdi, Penggunaan Asam Sulfat (H2SO4) Sebagai Stimulansia Dalam Meningkatkan Produktivitas Getah Pinus (Pinus Merkusii Jungh et de Vriese) Dengan Metode Riil, Universitas Sumatera Utara, 2013

3. D. A. R. Arimbi, Analisis Faktor-Faktor Yang Mempengaruhi Penawaran Ekspor Gondorukem Perum Perhutani, Institut Pertanian Bogor, 2008

4. I. C. Mandang, B. J. V. Polii, and H. . Walangitan, AGRI-SOSIOEKONOMI 14, 1 (2018)

5. Z. FANANI R. and H. SULIANTORO, J. Tek. Ind. 11, 178 (2012)

6. A. Abdillah, N. A. Deliarnoor, N. Y. Yuningsih, and F. Fatmawati, J. Contemp. Gov. Public Policy 1, 67 (2020)

7. F. R. David, Strategic Management: Concepts and Cases (11th Edition) 11th Edition (Pearson College Div, Pearson, 2006)

8. M. K. Sallata, Bul. Eboni 10, (2013)

9. Y. A. Adhi, Pengaruh Jumlah Sadapan Terhadap Produksi Getah Pinus (Pinus Merkusii) Dengan Metode Koakan Di Hutan Pendidikan Gunung Walat Kabupaten Sukabumi Jawa Barat, Institut Pertanian Bogor, 2008 